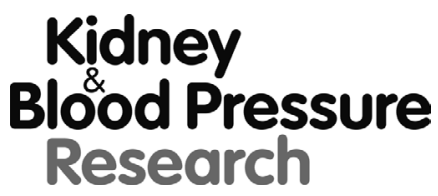

Kidney Blood Press Res 2018;43:780-792

DOI: $10.1159 / 000489914$

Published online: 22 May, 2018

Accepted: 9 May, 2018

This article is licensed under the Creative Commons Attribution-NonCommercial-NoDerivatives 4.0 International License (CC BY-NC-ND) (http://www.karger.com/Services/OpenAccessLicense). Usage and distribution tional License (CC BY-NC-ND) (http://www.karger.com/Services/OpenAccessLicense). Usage and dist

\title{
Add-On Effect of Angiotensin Receptor Blockade (Candesartan) on Clinical Remission in Active IgA Nephropathy Patients Treated with Steroid Pulse Therapy and Tonsillectomy: a Randomized, Parallel- Group Comparison Trial
}

\author{
Kentaro Kohagura ${ }^{\mathrm{a}, \mathrm{b}}$ Hisatomi Arimac Hitoshi Miyasato ${ }^{\mathrm{d}}$ Tung-Huei Chang ${ }^{\mathrm{e}}$ \\ Masanobu Yamazato ${ }^{a}$ Hiroyuki Koborif ${ }^{\text {Akira Nishiyamag Kunitoshi Iseki }{ }^{\mathrm{h}}}$ \\ Yusuke Ohya ${ }^{b}$
}

\begin{abstract}
aDialysis Unit, University of the Ryukyus Hospital, Okinawa, bDepartment of Cardiovascular Medicine, Nephrology and Neurology, Graduate School of Medicine, University of the Ryukyus, Okinawa, 'Department of Preventive Medicine and Public Health, Fukuoka University, Fukuoka, dOkinawa Chubu Prefectural Hospital, Okinawa, e Okinawa Heart Life Hospital, Okinawa, fDepartments of Pharmacology and Nephrology, School of Medicine, International University of Health and Welfare, Narita,

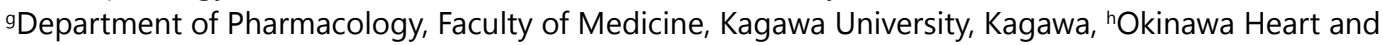
Renal Association (OHRA), Okinawa, Japan
\end{abstract}

\section{Key Words}

Angiotensin receptor inhibitor $\cdot$ Clinical remission $\cdot \operatorname{IgA}$ nephropathy $\cdot$ Steroid pulse therapy - Tonsillectomy

\begin{abstract}
Background/Aims: Angiotensin receptor blockers (ARBs) may be beneficial for clinical remission during conventional therapy with tonsillectomy and steroid pulse (TSP) for active IgA nephropathy. Methods: Seventy-seven patients with active IgA nephropathy were randomly assigned to the control arm with conventional regimen (TSP followed by oral prednisolone) $(n=37)$ or the ARB arm with conventional regimen plus ARB candesartan for the first 6 months $(n=40)$. Patients not achieving proteinuria remission at 12 months in either arm were administered candesartan, which was titrated until the 24-month follow-up. The primary endpoints were remission of proteinuria $(<0.3 \mathrm{~g} / \mathrm{gCr})$ and hematuria at 12 months. Results: Baseline proteinuria $(\mathrm{g} / \mathrm{g} \mathrm{Cr}$ ) were comparable between the the control and ARB arm (1.02 vs.
\end{abstract}




\section{Kidney Blood Pressure Research}

Kidney Blood Press Res 2018;43:780-792

\begin{tabular}{l|l}
\hline DOI: $10.1159 / 000489914$ & (C) 2018 The Author(s). Published by S. Karger AG, Basel
\end{tabular}

Published online: 22 May, 2018

www.karger.com/kb

781

$0.97, P=0.97)$. Similarly, cumulative remission rates at 6,12 , and 24 months were comparable between the control and ARB arms $(37.8 \%$ vs. $35 \%[P=0.80], 48.7 \%$ vs. $38.5 \%[P=0.37], 71.4 \%$ vs. $51.3 \%[P=0.08])$. Proteinuria, which was slightly worse in the control arm than in the ARB arm at 6 months, was comparable afterwards ( $0.20 \mathrm{vs.} 0.23 \mathrm{~g} / \mathrm{g} \mathrm{Cr}$ at 12 months; $0.12 \mathrm{vs} .0 .13$ $\mathrm{g} / \mathrm{g} \mathrm{Cr}$ at 24 months). Significant reductions observed in urinary angiotensinogen were almost comparable between the two treatment arms at both 6 and 12 months. Conclusion: Early candesartan treatment combined with TSP may not benefit clinical remission regardless of the blood pressure. ARB titration later during the treatment might provide benefit for patients with active IgA nephropathy.

(C) 2018 The Author(s)

Published by S. Karger AG, Basel

\section{Introduction}

IgA nephropathy is the most common primary glomerulonephritis worldwide, especially in Asia including Japan [1, 2]. Among primary glomerular diseases, IgA nephropathy is one of the leading causes of end-stage renal disease (ESRD)[3]. However, established therapies to prevent the progression of IgA nephropathy to ESRD are limited [4-6]. Clinical remission, defined as the resolution of proteinuria and hematuria, was shown to associate with favorable long-term outcomes [7-9]. Studies revealed that the contribution of glomerular capillary inflammation and glomerular hemodynamic abnormalities, two major pathogenic processes involved in IgA nephropathy, to the development of renal damage varied during the disease course [10]. Findings from recent basic and clinical studies suggest a fundamental role for abnormal mucosal immunity in the development of glomerular inflammation [11, 12]. The potential efficacy of tonsillectomy also supports the presence of a link between mucosal immunity and progression of IgA nephropathy $[13,14]$. Randomized control trials as well as observational studies suggest that combination therapy with tonsillectomy and steroid pulse therapy (TSP) might promote clinical remission [7, 14, 15]. Although TSP has been widely used in patients with IgA nephropathy in Japan [16], the reported remission rates vary widely $[10,16,17]$. Since clinical remission might potentially delay the progression of IgA nephropathy $[7,8]$, improving remission rates by TSP might promote favorable renal outcomes. However, factors contributing to improved remission rates remain unclear.

Among the proposed pathogenic processes underlying IgA nephropathy [4, 18], glomerular inflammation and the activation of the renin-angiotensin system (RAS), especially in the kidney, appear to be major contributors [19-21]. Resolution of glomerulonephritis by treatment approaches that can complement TSP might be crucial for clinical remission. For example, self-resolution of glomerular inflammation was shown in Thy1 nephritis, a model of mesangial proliferative glomerulonephritis [22]. However, concurrent nephrectomy has the potential to redirect self-resolution into a progressive phenotype in which glomerulonephritis might develop [22]. Studies showing augmentation of renal RAS in nephrectomized animals [23] as well as in patients with IgA nephropathy [21,24] suggest that renal RAS might be responsible for both glomerular hypertension and glomerular inflammation. Moreover, RAS is well known to activate inflammatory processes [25] and vice versa [26], leading to a vicious cycle. In support of the potential role of RAS activation in nephropathy, angiotensin receptor blockers (ARBs) were shown to attenuate crescent formation [27].

We hypothesized that RAS inhibition, independent from its role in blood pressure regulation, might improve the efficacy of TSP in achieving clinical remission by blocking renal RAS and alleviating secondary glomerular hypertension. In this randomized, openlabeled control study, we evaluated the effects of short-term combination treatment with the ARB candesartan and TSP in patients with active IgA nephropathy. 


\section{Kidney Blood Pressure Research}

Kidney Blood Press Res 2018;43:780-792

\begin{tabular}{l|l}
\hline DOI: $10.1159 / 000489914$ & (C) 2018 The Author(s). Published by S. Karger AG, Basel
\end{tabular}

Published online: 22 May, 2018 www.karger.com/kbr

Kohagura et al:: Add-On Effect of ARB to Tonsillectomy and Steroid Pulse in IgA Nephropathy

\section{Materials and Methods}

\section{Study Design}

This open-label, and randomized clinical trial (ACTRN12610000516088) was conducted at three institutions, including one university and two community hospitals, in Okinawa, Japan. The study protocol was approved by the institutional review board of the University of the Ryukyus and was conducted in accordance with the Declaration of Helsinki and national guidelines; furthermore, all patients provided written informed consent.

\section{Patients}

Patients between the ages of 15 and 70 years with histologically proven IgA nephropathy were eligible if they fulfilled the following inclusion criteria: urinary protein $\geq 0.5 \mathrm{~g} / \mathrm{gCr}$; serum creatinine $\leq 1.5 \mathrm{mg} / \mathrm{dL}$; and active glomerular lesions defined by the presence of necrosis, crescent formation, or urinary red blood cell count $\geq 10$ /high-power field (HPF) for a minimum of 3 months. The exclusion criteria were as follows: contraindications to ARBs, treatment with a RAS inhibitor within 4 weeks before enrollment, diabetes mellitus, severe hypertension defined as $\geq 200 \mathrm{mmHg}$ systolic blood pressure or $\geq 100 \mathrm{mmHg}$ diastolic blood pressure, and recent onset of cardiovascular disease. Treatment was discontinued 4 weeks before enrollment and after obtaining informed consent in patients taking RAS inhibitors.

Comorbidities in this analysis were defined as follows. Hypertension was defined as $>2$ ambulatory blood pressure of $\geq 140 \mathrm{mmHg}$ systolic and/or $90 \mathrm{~mm} \mathrm{Hg}$ diastolic, or treatment with antihypertensive agents. Diabetes mellitus was defined as $\geq 2$ fasting plasma glucose level measurements of $\geq 126 \mathrm{mg} / \mathrm{dl}$, a 2-h plasma glucose level of $\geq 200 \mathrm{mg} / \mathrm{dl}$, or treatment with hypoglycemic agents. Dyslipidemia was defined as a low-density lipoprotein cholesterol level of $\geq 140 \mathrm{mg} / \mathrm{dl}$, high-density lipoprotein cholesterol level of $<40 \mathrm{mg} / \mathrm{dl}$, triglyceride level of $\geq 150 \mathrm{mg} / \mathrm{dl}$, or treatment with specific lipid-lowering agents. The baseline height and weight were recorded, and the body mass index (BMI) was calculated. Serum creatinine levels were measured using an enzymatic method. The estimated glomerular filtration rate (eGFR) was calculated using the Japanese Society of Nephrology formula [28] as follows:

eGFR $(\mathrm{mL} / \mathrm{min}$ per $1.73 \mathrm{~m} 2=194 \times$ serum creatinine $1.094 \times$ age 0.287 ( $\times 0.739$ if female $)$.

\section{Randomization and allocation to treatment groups}

Allocation to treatment arms was achieved using sealed opaque envelopes prepared by an independent assistant and consisted of random permuted blocks of size 8 with stratification according to proteinuria (1 $\mathrm{g} / \mathrm{gCr}$ ) and duration from the onset of urinary abnormality (3 years), as both could potentially affect the remission rate [17]. A sample size of 80 patients was calculated based on a significant level ( $\alpha$ error) of 0.05 , a $\beta$ error of 0.2 , a power $(1-\beta)$ of 0.8 with predicted clinical remission rates of $40 \%$ and $70 \%$ in the control and ARB arms, respectively, at 12 months and a predicted dropout rate of $30 \%$ based on our historical population.

\section{Study protocol}

As shown in Fig. 1, control patients $(\mathrm{n}=37)$ were scheduled to receive standard treatment with steroid pulse followed by oral prednisolone for 6 months and tonsillectomy within 6 months after steroid pulse therapy. Since steroid pulse are generally superior for rapid resolution of inflammatory process, patients with diffuse active lesion are supposed to be better for starting treatment with steroid pulse. Thus steroid pulse was performed prior to tonsillectomy in standard treatment. Patients in the ARB $\operatorname{arm}(n=40)$ were scheduled to receive standard regimen plus candesartan for 6 months. Those who did not achieve remission in either arm, as determined by the presence of proteinuria at 12 months, were scheduled to receive candesartan which was planned to be titrated until the 24 -month visit. High-dose methylprednisolone $(0.5 \mathrm{~g} /$ day, three times a week for 3 consecutive weeks) as steroid pulse therapy was followed by oral prednisolone at an initial dose of $30 \mathrm{mg}$ every other day with gradual tapering over six months. Tonsillectomy was performed after steroid pulse therapy during the first six months by an otolaryngologist after obtaining informed consent, regardless of the gross appearance of tonsils and even in the absence of episodes of recurrent tonsillitis or gross hematuria with tonsillitis. Candesartan was initially adminstered at a dose of 2-8 $\mathrm{mg} /$ day, followed 


\section{Kidney \\ Blood Pressure Research}

Kidney Blood Press Res 2018;43:780-792

\begin{tabular}{l|l}
\hline DOI: $10.1159 / 000489914$ & (C) 2018 The Author(s). Published by S. Karger AG, Basel
\end{tabular}

Published online: 22 May, 2018 www.karger.com/kbr

by titration to achieve remission of proteinuria to a max dose of $12 \mathrm{mg} /$ day, unless symptomatic hypotension emerged as a complication.

\section{Outcome measures}

The primary endpoint was the rate of clinical remission at 12 months, and the secondary endpoints were clinical remission rates at 6 and 12 months and the levels of urinary protein, urinary red blood cell, and estimated glomerular filtration rate. Previous study demonstrated that even trace proteinuria would be associated with renal event [29]. Kohagura et al.: Add-On Effect of ARB to Tonsillectomy and Steroid Pulse in IgA Nephropathy

Thus, clinical remission was originally

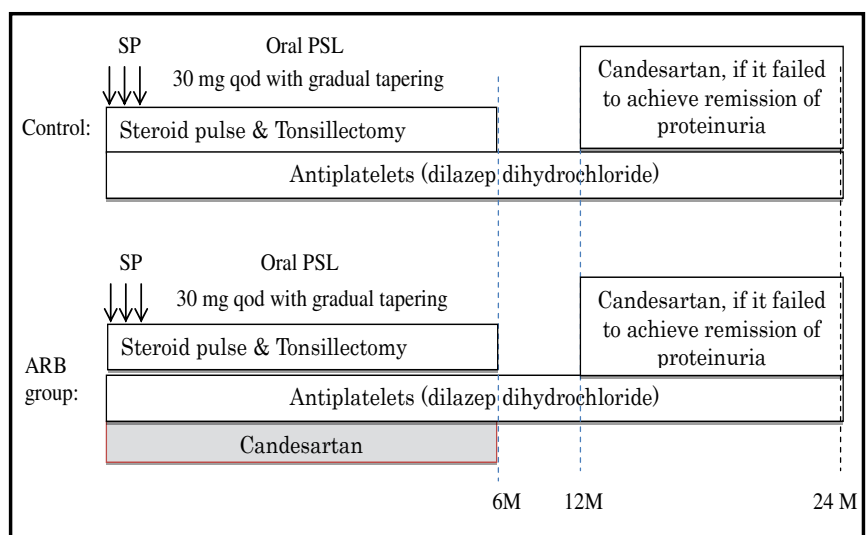

Fig. 1. Study protocol. ARB: angiotensin receptor blocker; $\mathrm{M}$ : months; PSL: prednisolone; SP: steroid pulse. defined as a urinary protein level $<0.2 \mathrm{~g} / \mathrm{gCr}$ and urinary red blood cell count $<5 / \mathrm{HPF}$ lasting for a duration of 2-3 months, determined at two consecutive visits. However, Japanese society of nephrology proposed the criteria of clinical remission of IgA nephropathy, recently. Thus we determined remission rate using modified definition of urinary protein levels $<0.3 \mathrm{~g} / \mathrm{gCr}$ according to the proposed definition [30]. We also examined the rate of clinical remission by subgroup of urinary protein level $\geq 1.0 \mathrm{~g} / \mathrm{gCr}$.

\section{Measurement of urinary angiotensinogen}

Angiotensin-converting enzyme 2 (ACE2) is highly expressed in the kidneys and degrades angiotensin (Ang) II to Ang-(1-7); it is suggested to have an important role in the progression of hypertension and renal diseases, including IgA nephrolathy [31]. Thus, urinary Ang-(1-7) is a potential marker of intrarenal RAS. Contrarily, urinary angiotensinogen (AGT) is known to be a superior biomarker of intrarenal RAS[24]. Moreover, previous reports showed that urinary AGT levels were elevated in patients with IgA nephropathy, which positively correlated with renal angiotensinogen gene expression and Ang II immunoreactivity [21]. Additionally, its levels were reduced, accompanied with reduction of proteinuria after treatment with ARB[21]. Therefore, we measured urinary AGT levels as a marker of intrarenal RAS. Levels of urinary angiotensinogen (AGT) in spot urine to evaluate renal RAS were measured using a novel sandwich enzymelinked immunosorbent assay at the University of Kagawa in Japan, as described previously [32, 33], and urinary AGT/creatinine ratio (UAGTCR, $\mu \mathrm{g} / \mathrm{gCr}$ ) was determined. The intra- and inter-assay coefficients of AGT measurements were $<10 \%$.

\section{Histological analysis}

Histological analysis was performed according to the Oxford classification of IgA nephropathy [33] by the same physician at the University Hospital of Ryukyus who was blinded to clinical information. The presence of extracapillary lesions was also assessed.

\section{Statistical analyses}

Baseline characteristics were expressed as mean (standard deviation [SD]), median (interquartile range) or $\mathrm{N}(\%)$ and compared between randomized groups using Wilcoxon rank-sum test or chi-square test as appropriate. Effects of randomized treatment on the primary outcome (remission rate) at each time point was evaluated using univariable and multivariable logistic regression models. Stratified analysis by proteinuria $(<1 \mathrm{~g} / \mathrm{gCr}$ vs $\geq 1 \mathrm{~g} / \mathrm{gCr}$ ) was also conducted for the primary outcome. Outcomes of continuous variables (urinary protein, angiotensinogen andeGFR) ateach time pointwere compared between randomized groups using one-way analysis of variance (ANOVA) for crude analysis and analysis of covariance (ANCOVA) for multivariable analysis. Urinary red blood cell grade between randomized groups were compared using multinomial logistic regression models. $P$ values $<0.05$ were considered statistically significant. All 


\section{Kidney \\ Blood Pressure Research}

Kidney Blood Press Res 2018;43:780-792

\begin{tabular}{l|l}
\hline DOI: 10.1159/000489914 & (C) 2018 The Author(s). Published by S. Karger AG, Basel
\end{tabular}

Published online: 22 May, 2018 www.karger.com/kbr

Nephropathy

statistical analyses were performed in blinded fashion by Dr. Arima who did not recruit any patients using SAS release 9.4 (SAS Institute Inc, Cary, NC).

\section{Results}

Enrollment began on April 17, 2007 and ended on December 31, 2011; the last patient enrolled in the study ended treatment on April 27, 2014. A total of 77 eligible patients who provided written informed consent were randomly allocated to either the control $(n=37)$ or the ARB $(\mathrm{n}=40) \mathrm{arm}$. Three patients

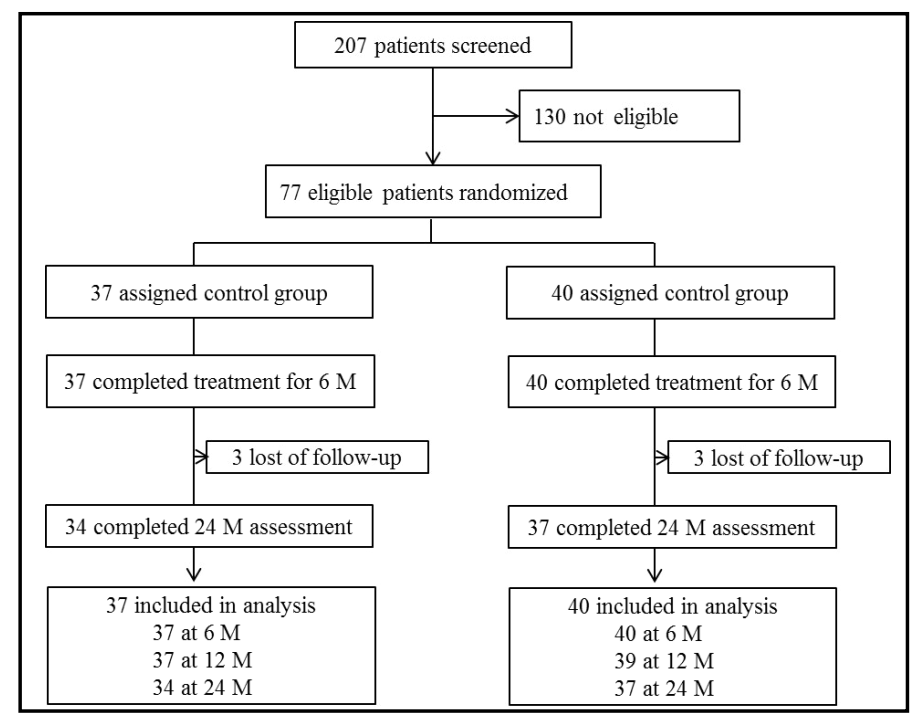

Fig. 2. Patient flow. Abbreviations are shown in the legend of Fig. 1.

in each group were lost to followup because they had not visited the clinic until 24M. Therefore, 34 patients in the control arm and 37 patients in the ARB arm completed the study with the final follow-up at 24 months (Fig. 2). The analysis was done by original assigned group including five patients who were lost of follow-up from $12 \mathrm{M}$ to $24 \mathrm{M}$ since their data for primary outcome were available.

\section{Baseline clinical characteristics}

As shown in Table 1, there were no significant differences in baseline clinical and histological characteristics including age, systolic blood pressure, eGFR, and urinary protein levels between the control and the ARB arms. The percentages of patients with urine protein $\geq 1 \mathrm{~g} /$ gCr was $46 \%$ and $50 \%$ in the control and $\mathrm{ARB}$ arms, respectively.

\section{Remission rates}

Although, clinical remission defined as $\mathrm{UP}<0.3 \mathrm{~g} / \mathrm{gCr}$ and urinary red blood cell count $<5$ / HPF) were comparable between the two treatment arms at 12 months, as well as at 6 and 24 months, remission rate at 24 month was

Table 1. Baseline characteristics of patients after randomization. Data are expressed as means (standard deviation), medians (interquartile range), or numbers (\%). ARB: angiotensin receptor blocker; ACE: angiotensinconverting enzyme; eGFR: estimated glomerular filtration rate; HPF: high-power field; MR: mineralocorticoid receptor; RAS: renin-angiotensin inhibitor; RBC: red blood cell

\begin{tabular}{|c|c|c|c|}
\hline Characteristics & Control $(\mathrm{N}=37)$ & ARB $(\mathrm{N}=40)$ & P value \\
\hline Age, years & $35.8(14.6)$ & $36.3(12.8)$ & 0.863 \\
\hline Female & $24(65 \%)$ & $19(48 \%)$ & 0.125 \\
\hline Years from onset, year & 4 (2 to 8$)$ & 3 (1 to 7 ) & 0.263 \\
\hline Body mass index (BMI), $\mathrm{kg} / \mathrm{m}^{2}$ & $24.7(4.0)$ & $23.1(3.1)$ & 0.666 \\
\hline $\mathrm{BMI} \geq 25 \mathrm{~kg} / \mathrm{m}^{2}$ & $13(35 \%)$ & $10(25 \%)$ & 0.332 \\
\hline Diabetes & $0(0 \%)$ & $3(8 \%)$ & 0.089 \\
\hline Hypertension & $7(19 \%)$ & $14(35 \%)$ & 0.113 \\
\hline SBP (mmHg) & $120(14)$ & $121(16)$ & 0.764 \\
\hline $\mathrm{DBP}(\mathrm{mmHg})$ & $73(10)$ & $73(14)$ & 0.959 \\
\hline Serum creatinine (mg/dl) & $0.8(0.2)$ & $0.8(0.2)$ & 0.648 \\
\hline $\mathrm{eGFR}\left(\mathrm{ml} / \mathrm{min} / 1.73 \mathrm{~m}^{2}\right)$ & $85(29)$ & $84(24)$ & 0.988 \\
\hline Urinary protein $(\mathrm{g} / \mathrm{gCr})$ & 0.9 (0.7 to 1.2$)$ & 1.0 (0.6 to 1.5$)$ & 0.968 \\
\hline Urinary protein $>1 \mathrm{~g} / \mathrm{gCr}$ & $17(46 \%)$ & $20(50 \%)$ & 0.722 \\
\hline \multicolumn{4}{|l|}{ Urinary sediment $\mathrm{RBC}$ count } \\
\hline Grade0 $(<5 / \mathrm{HPF})$ & $0(0 \%)$ & $5(13 \%)$ & 0.186 \\
\hline Grade1 (5-9/HPF) & $7(19 \%)$ & $5(13 \%)$ & \\
\hline Grade2 $(10-19 / \mathrm{HPF})$ & $9(24 \%)$ & $11(28 \%)$ & \\
\hline Grade3 $(20-29 / \mathrm{HPF})$ & $8(22 \%)$ & $5(13 \%)$ & \\
\hline Grade4 (>30/HPF) & $13(35 \%)$ & $13(33 \%)$ & \\
\hline Antihypertensive drugs & $10(27 \%)$ & $15(38 \%)$ & 0.327 \\
\hline ARB & $5(14 \%)$ & $7(18 \%)$ & 0.596 \\
\hline ACE inhibitors & $2(6 \%)$ & $0(0 \%)$ & 0.131 \\
\hline RASI & $6(16 \%)$ & $7(18 \%)$ & 0.883 \\
\hline Calcium channel blocker & $6(3 \%)$ & $9(23 \%)$ & 0.487 \\
\hline Beta blocker & $1(3 \%)$ & $1(3 \%)$ & 0.955 \\
\hline Alpha blocker & $1(3 \%)$ & $0(0 \%)$ & 0.296 \\
\hline Diuretics & $1(3 \%)$ & $2(5 \%)$ & 0.603 \\
\hline MR antagonists & $0(0 \%)$ & $84(24)$ & 0.603 \\
\hline \multicolumn{4}{|l|}{ Pathologic parameters } \\
\hline M1 & $21(57 \%)$ & $15(38 \%)$ & 0.091 \\
\hline En1 & $13(35 \%)$ & $18(45 \%)$ & 0.378 \\
\hline S1 & $24(65 \%)$ & $28(70 \%)$ & 0.631 \\
\hline Ex1 (\%) & $11(6-22)$ & $13(8-24)$ & 0.313 \\
\hline \multicolumn{4}{|c|}{ Tubular atrophy/ Interstitial fibrosis } \\
\hline т0 & $25(68 \%)$ & $27(69 \%)$ & 0.178 \\
\hline $\mathrm{T} 1$ & $9(24 \%)$ & $12(31 \%)$ & \\
\hline T2 & $3(8 \%)$ & $0(0 \%)$ & \\
\hline
\end{tabular}




\section{Kidney Blood Pressure Research}

rather favor for control arms as shown in Table2. Titration of candesartan from 12-months improved remission rate at 24-monthsin either arms. The dose of candesartane (median, minimum to max) were $8 \mathrm{mg}(2 \mathrm{mg}-$ $12 \mathrm{mg})$ and $8 \mathrm{mg}(2-12 \mathrm{mg})$, respectively.

Remission rates among patients with urinary protein levels $<1$ $\mathrm{g} / \mathrm{gCr}$ were $45 \%$ and $35 \%$ at 6 months, $50 \%$ and $52.6 \%$ at 12 months, and $77.8 \%$ and $57.9 \%$ at 24 months in the control and ARB arms, respectively. Among patients with urinary protein levels $\geq 1 \mathrm{~g} /$ $\mathrm{gCr}$, remission rates were $29.4 \%$ and $35.0 \%$ at 6 months, $47.1 \%$ and $25 \%$ at 12 months, and $64.7 \%$ and $45 \%$ in the control and ARB arms, respectively (Table 3).

Urinary protein level, red blood cell grade, and estimated glomerular filtration rate

Mean urinary protein levels of 1.02 and 0.97 $\mathrm{g} / \mathrm{gCr}$ in the control and ARB arms, respectively, at baseline were markedly reduced to 0.21 and 0.11 g/gCr at 6 months (Fig. 3). Although mean urinary protein in the ARB arm was significantly lower than that in the control arm at 6 months, mean urinary protein levels were comparably maintained at around $0.1 \mathrm{~g} / \mathrm{gCr}$ afterword.

Assessment of hematuria revealed that urinary red blood cell (RBC) grades were significantly lower in the control arm than in the ARB arm at all follow-up points (Table 4). No significant changes in eGFR were observed in either treatment arm at 24 months (Fig. 4).

\section{Blood pressure}

Blood pressure was well controlled in both groups at baseline. Mean systolic and diastolic blood pressure values (SD) in the control and ARB arms for 6, 12, and 24 months are indicated in Table 5. Systolic blood pressure was strictly and comparably controlled at around $110 \mathrm{mmHg}$ in both groups from 6 months until 24 months.

\section{Urinary angiotensinogen levels}

As shown in Fig. 5, urinary AGT levels were reduced at 6 months and remained at comparably low levels thereafter in both the control and ARB arms. Mean urinary AGT in the ARB arm was transiently increased at 12 months after discontinuation of ARB. Conversely, urinary AGT levels in control arm were sustainably decreased at 12 months compared to 6 months. Importantly, mean urinary AGT levels in both treatment arms were decreased at 24 months after the addition of ARB to treatment of patients who not achieve remission based on the presence of proteinuria.
Table 3. Remission rates at each visit stratified by baseline urinary protein level. Remission was defined as $<0.3 \mathrm{~g} / \mathrm{gCr}$ and $<5$ angiotensin receptor blocker

\begin{tabular}{lccc}
\hline Time & $\begin{array}{c}\text { Basal urinary } \\
\text { protein }\end{array}$ & Control (N=37) & ARB (N=40) \\
\hline 6 months & $<1 \mathrm{~g} / \mathrm{gCr}$ & $9 / 20(45.0 \%)$ & $7 / 20(35.0 \%)$ \\
& $\geq 1 \mathrm{~g} / \mathrm{gCr}$ & $5 / 17(29.4 \%)$ & $7 / 20(35.0 \%)$ \\
12 months & $<1 \mathrm{~g} / \mathrm{gCr}$ & $10 / 20(50.0 \%)$ & $10 / 19(52.6 \%)$ \\
& $\geq 1 \mathrm{~g} / \mathrm{gCr}$ & $8 / 17(47.1 \%)$ & $5 / 20(25.0 \%)$ \\
24 months & $<1 \mathrm{~g} / \mathrm{gCr}$ & $14 / 18(77.8 \%)$ & $11 / 19(57.9 \%)$ \\
& $\geq 1 \mathrm{~g} / \mathrm{gCr}$ & $11 / 17(64.7 \%)$ & $9 / 20(45.0 \%)$
\end{tabular}




\section{Kidney \\ Blood Pressure Research}

Kidney Blood Press Res 2018;43:780-792

DOI: 10.1159/000489914

Published online: 22 May, 2018

(C) 2018 The Author(s). Published by S. Karger AG, Basel www.karger.com/kbr

Fig. 3. Time course of urinary protein by randomized group. Blank circles represent average in the control group; black squares, average in the ARB group; vertical lines, confidence intervals. \# $\mathrm{p}=0.002$ in crude analysis. * $\mathrm{p}=0.005$ after adjustment for age, sex, obesity, hypertension, diabetes mellitus, estimated glomerular filtration rate at baseline and randomized group (model 1).**model1 + baseline angiotensinogen, $\mathrm{p}=0.0004$. ***model $1+$ angiotensinogen change Kohagura et al.: Add-On Effect of ARB to Tonsillectomy and Steroid Pulse in IgA Nephropathy

(from baseline to 6 months), $\mathrm{p}=0.001$.

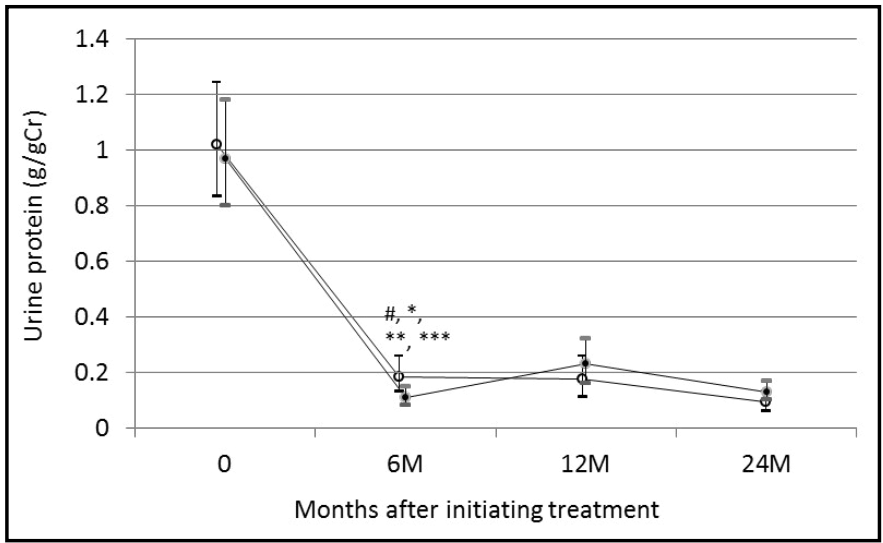

Table 4. Time course of urinary red blood cell scores over time by randomized group. $\mathrm{P}$ values were tested using chi-squared test. RBC: red blood cell; ARB: angiotensin receptor inhibitor. *model1: Adjusted for age, sex, obesity, hypertension, diabetes mellitus, estimated glomerular filtration rate at baseline and randomized group. ${ }^{* *}$ model $1+$ baseline angiotensinogen. ${ }^{* * *}$ model $1+$ angiotensinogen change (from baseline to 6 months)

\begin{tabular}{|c|c|c|c|c|c|c|c|}
\hline Time & U RBC & Control & ARB & $P$ value & $P$ adjusted $*$ & $\mathrm{P}$ adjusted $* *$ & $\mathrm{P}$ adjusted $* * *$ \\
\hline \multirow[t]{5}{*}{ Baseline } & 0 & $0 / 37(0 \%)$ & $5 / 39(13 \%)$ & 0.186 & 0.371 & 0.684 & 0.207 \\
\hline & 1 & $7 / 37(19 \%)$ & $5 / 39(13 \%)$ & & & & \\
\hline & 2 & $9 / 37(24 \%)$ & $11 / 39(28 \%)$ & & & & \\
\hline & 3 & $8 / 37(22 \%)$ & $5 / 39(13 \%)$ & & & & \\
\hline & 4 & $13 / 37(35 \%)$ & $13 / 39(33 \%)$ & & & & \\
\hline \multirow[t]{5}{*}{6 months } & 0 & $21 / 37(57 \%)$ & $15 / 40(38 \%)$ & 0.251 & 0.064 & 0.156 & 0.042 \\
\hline & 1 & $7 / 37$ (19\%) & $13 / 40(33 \%)$ & & & & \\
\hline & 2 & $6 / 37(16 \%)$ & $4 / 40(10 \%)$ & & & & \\
\hline & 3 & $1 / 37(3 \%)$ & $3 / 40(8 \%)$ & & & & \\
\hline & 4 & 2/37 (5\%) & $5 / 40(13 \%)$ & & & & \\
\hline \multirow[t]{5}{*}{12 months } & 0 & $30 / 37(81 \%)$ & $21 / 37(57 \%)$ & 0.060 & 0.005 & 0.013 & 0.021 \\
\hline & 1 & $6 / 37(16 \%)$ & $11 / 37(30 \%)$ & & & & \\
\hline & 2 & $1 / 37(3 \%)$ & $0 / 37(0 \%)$ & & & & \\
\hline & 3 & $0 / 37(0 \%)$ & $2 / 37(5 \%)$ & & & & \\
\hline & 4 & $0 / 37(0 \%)$ & $3 / 37$ (8\%) & & & & \\
\hline \multirow[t]{5}{*}{24 months } & 0 & $29 / 34(85 \%)$ & $23 / 36(64 \%)$ & 0.008 & 0.028 & 0.032 & 0.014 \\
\hline & 1 & $3 / 34(9 \%)$ & $2 / 36(6 \%)$ & & & & \\
\hline & 2 & $0 / 34(0 \%)$ & $7 / 36(19 \%)$ & & & & \\
\hline & 3 & $2 / 34(6 \%)$ & $0 / 36(0 \%)$ & & & & \\
\hline & 4 & $0 / 34(0 \%)$ & $4 / 36(11 \%)$ & & & & \\
\hline
\end{tabular}

Fig. 4. Time course in estimated glomerular filtration rate by randomized group. Blank circles represent average in the control group; black squares, average in the ARB group; vertical lines, confidence intervals. Adjustment for age, sex, obesity, hypertension, diabetes mellitus, estimated glomerular filtration rate at baseline and randomized group (model 1). *model1 + baseline angiotensinogen, $\mathrm{p}=0.032$.

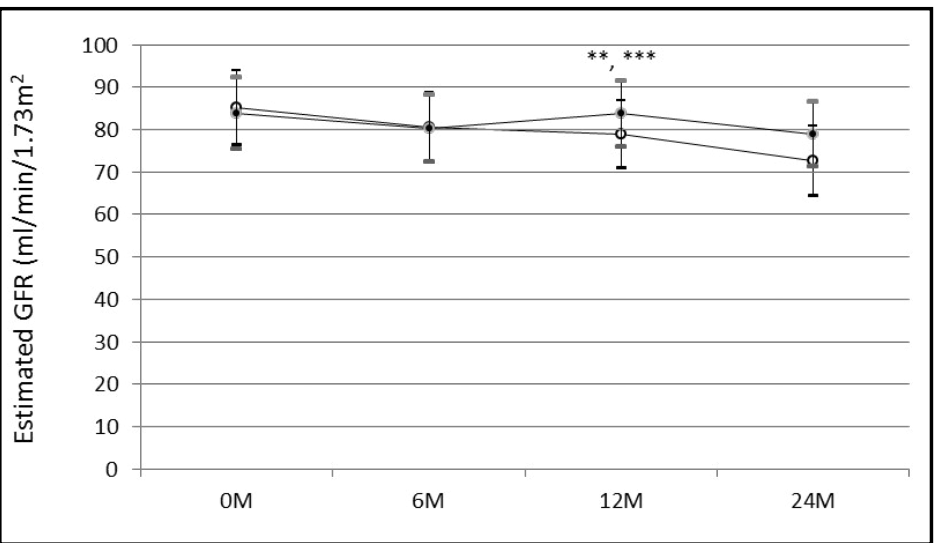
**model1 + angiotensinogen change (from baseline to 6 months), $\mathrm{p}=0.024$. 


\section{Kidney \\ Blood Pressure Research}

Kidney Blood Press Res 2018;43:780-792

\begin{tabular}{l|l}
\hline DOI: 10.1159/000489914 & (C) 2018 The Author(s). Published by S. Karger AG, Basel
\end{tabular}

Published online: 22 May, 2018 www.karger.com/kbr

Table 5. Time course of blood pressure. *Wilcoxon test

Kohagura et al.: Add-On Effect of ARB to Tonsillectomy and Steroid Pulse in IgA Nephropathy

\begin{tabular}{lcccc}
\hline Variable & Time & Control & ARB & P value* $^{*}$ \\
\hline Systolic blood pressure, & Baseline & $120(14)$ & $121(16)$ & 0.764 \\
mmHg & 6 months & $112(12)$ & $109(14)$ & 0.087 \\
& 12 months & $113(12)$ & $113(11)$ & 0.996 \\
& 24 months & $113(12)$ & $112(13)$ & 0.581 \\
Diastolic blood pressure, & Baseline & $73(10)$ & $73(14)$ & 0.959 \\
mmHg & 6 months & $69(9)$ & $67(9)$ & 0.268 \\
& 12 months & $70(8)$ & $70(9)$ & 0.836 \\
& 24 months & $68(11)$ & $68(10)$ & 0.897 \\
\hline
\end{tabular}

Fig. 5. Time course of urinary anginotensinogen by randomized group. Blank circles represent average in the control group; black squares, average in the ARB group; vertical lines, confidence intervals. ${ }^{*} \mathrm{p}=0.031$ after adjustment for age, sex, obesity, hypertension, diabetes mellitus, estimated glomerular filtration rate at baseline, randomized group and baseline angiotensinogen. AGT was log-transformed to remove skewness. Mean values were obtained by backtransformation. $\mathrm{P}$ values were tested

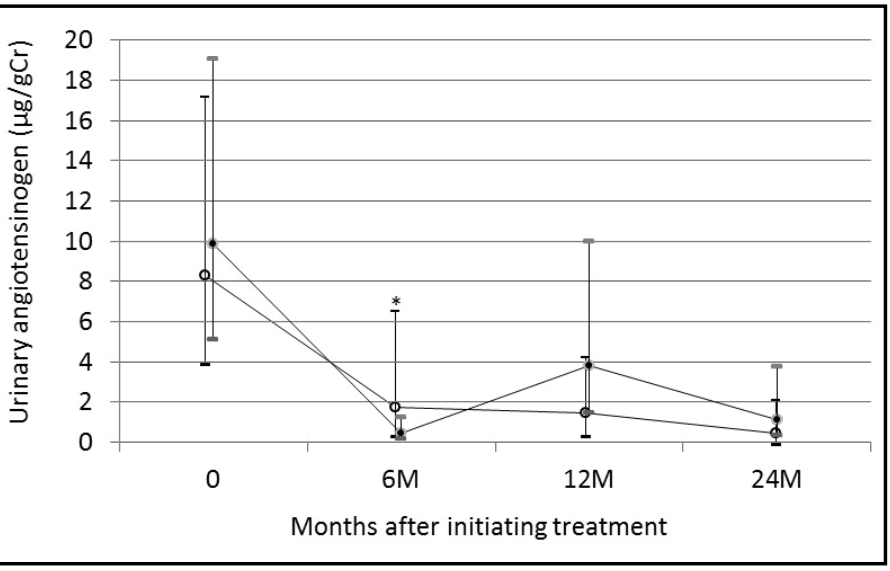
using analysis of variance.

\section{Adverse events}

All participants completed 6 months of therapy without any serious adverse events such as infections requiring hospitalization. One patient in the control arm and two patients in the ARB arm experienced worsening of hemoglobin A1c, which was around $6 \%$ at 6 months; the patient in the control arm was treated with an alpha-glucosidase inhibitor and glucose controls of the two patients in the ARB arm naturally improved with steroid dose reduction. One patient in the control arm temporarily developed partial alopecia. One female patient in each of the ARB and control arms became pregnant at 6 and 23 months after the commencement of the study, and both discontinued all medications including study drugs.

\section{Discussion}

The findings of this trial demonstrated that the significant reduction in proteinuria observed in patients receiving TSP-based therapy without candesartan at 6 months was further enhanced by the concomitant use of candesartan in patients with active IgA nephropathy and active glomerular lesions. However, concomitant use of candesartan independent of its blood pressure-lowering effects did not improve the clinical remission rate achieved by TSP-based treatment at neither 6 nor 12 months. Importantly, candesartan administration to patients who did not achieve clinical remission in either treatment arm, regardless of their blood pressure levels, effectively reduced urinary protein levels and eventually led to increased clinical remission rates.

Previous studies suggested that the interplay between inflammation and RAS might play a role in the clinical progression of IgA nephropathy [34, 35]. Moreover, treatment with ARBs regardless of the blood pressure levels was demonstrated to be effective in reducing 


\section{Kidney Blood Pressure Research}

Kidney Blood Press Res 2018;43:780-792

\begin{tabular}{l|l}
\hline DOI: $10.1159 / 000489914$ & (C) 2018 The Author(s). Published by S. Karger AG, Basel
\end{tabular}

Published online: 22 May, 2018

www.karger.com/kb

proteinuria [36]. However, short-term, concomitant use of candesartan was not associated with improvement in the clinical remission rate among IgA nephropathy patients treated with TSP in the present study. Notably, while candesartan was administered only in the ARB arm during the first 6 months, the urinary protein levels of most patients in both treatment arms were around $0.2 \mathrm{~g} / \mathrm{gCr}$ within 6 months after the study commencement date and were maintained at comparable levels until 12 months. These findings hint at the favorable impact of the TSP-based therapy itself on the resolution of active glomerulonephritis, as demonstrated by previous studies [7, 37]. Therefore, inhibition of RAS with ARBs such as candesartan might have a limited role in achieving remission during the early phase of TSP-based treatment. Alternatively, resolution of inflammatory processes by blocking angiotensin type 1 receptor might be limited, since angiotensin II was shown to activate nuclear transcription factor-kappa B (NF- $\kappa$ B) via angiotensin type 2 receptor as well as type 1 receptor [25]. In general, the effects of RAS inhibitors are supposed to be primarily mediated by the alteration of glomerular hemodynamics. In reality, addition of candesartan for the first 6 months significantly reduced proteinuria to $0.1 \mathrm{~g} / \mathrm{g}$ Cr with greater reduction of the urinary AGT level. Therefore, the duration of treatment with candesartan appeared to sufficiently reduce proteinuria in the early phases of TSP-based treatment. Moreover, RAS blockade with candesartan was supposed to be sufficient to suppress intrarenal RAS and proteinuria, although we did not use dual blockade with ARB and ACE inhibitors.

Although an additional benefit with candesartan during the early phase of TSP-based therapy in IgA nephropathy was not demonstrated, its addition to therapy regardless of the blood pressure levels of patients was beneficial in reducing proteinuria and eventually improving the clinical remission rate in patients who would not otherwise achieve clinical remission during the later phase of TSP-based therapy. Moreover, reducing proteinuria by addition of candesartan was accompanied by a reduction in urinary AGT. Since renal RAS was suggested to regulate glomerular hemodynamics [38], these observations suggested that glomerular hypertension might be responsible for residual proteinuria. Alterations in the autoregulation system in afferent arterioles, which maintains glomerular blood pressure levels at around $50 \mathrm{mmHg}$ over a wide range of systemic blood pressure levels, leads to the direct transmission of systemic blood pressure to glomeruli without sufficient reduction. Therefore, even a normal range of systemic blood pressure might be associated with glomerular hypertension and might result in increased proteinuria. We recently reported that hyalinosis in renal arterioles, a potential marker for dysregulation of the autoregulation system, was associated with higher urinary protein levels and greater reductions in eGFR than those seen in patients without hyalinosis, even within the normal range of blood pressure in IgA nephropathy [39]. Moreover, we reported that uric acid may augment susceptibility for hypertensive glomerular damage in association with evoking renal arteriolopathy in IgA nephropathy [40]. Consistent with this hypothesis, uric acid was reportedly associated with the progression of IgA nephropathy [41]. Titration of ARB regardless of the systemic blood pressure levels of patients might be crucial for achieving clinical remission, especially in patients who have not yet achieved it.

Surprisingly, this study showed that even TSP-only treatment successfully reduced the urinary levels of AGT, a marker of renal RAS status. Previous studies demonstrated that activation of renal RAS observed in patients with IgA nephropathy could be reversed by ARBs [21]. The benefit of TSP in IgA nephropathy appears to be based on its efficacy in resolution of inflammation in the glomerulus and reduction in the production of abnormally glycosylated IgA in the tonsils [42]. NF- $\kappa \mathrm{B}$, a mediator of inflammation, is proposed to be involved in the development of IgA nephropathy [43]. Since NF- $\kappa B$ is a transcriptional activator of AGT [26] that modulates angiotensin II-mediated responses, resolution of inflammation by TSP alone might be sufficient even in the absence of ARBs. Moreover, TSPmediated reduction in proteinuria might underlie the decreases observed in urinary AGT levels, since proteinuria was reported to be associated with NF- $\kappa \mathrm{B}$-dependent activation of renal RAS [44]. Alternatively, increases in urinary AGT might result from injured glomerular 


\section{Kidney \\ Blood Pressure Research}

Kidney Blood Press Res 2018;43:780-792

\begin{tabular}{l|l}
\hline DOI: $10.1159 / 000489914$ & (C) 2018 The Author(s). Published by S. Karger AG, Basel
\end{tabular}

Published online: 22 May, 2018

www.karger.com/kb

Kohagura et al:: Add-On Effect of ARB to Tonsillectomy and Steroid Pulse in IgA Nephropathy

capillary and might return to normal levels following resolution of glomerular inflammation. Additional treatment with candesartan effectively reduced both proteinuria and urinary AGT in patients not achieving clinical remission in both treatment arms, suggesting that alterations in renal AGT might be contributing to residual proteinuria in these patients, which could be reversed by ARBs, in agreement with a previous report [21].

The present study has several limitations. First, the number of enrolled subjects was relatively low, which might adversely affect the robust elucidation of the efficacy of shortterm candesartan treatment. Given that even TSP-only treatment led to significant reductions in urinary protein demonstrating the additional benefit of candesartan for remission might be challenging. Second, the duration of follow-up oral steroid therapy for 6 months after TSP might be short, given that treatment with oral prednisolone after TSP was maintained for 12 months in the original protocol reported by Hotta et al. which showed more favorable remission rates [7]. Third, the grade of hematuria was relatively higher in the ARB arm at 6 months, suggesting the presence of potential bias in disease activity between the two treatment arms that was not evident by usual clinical and histological assessment conducted at baseline. Fourth, since relatively mild cases were recruited in this study, the findings might not be applicable to more severe IgA nephropathy cases. Finally, urinary findings could not be followed up beyond 24 months after study initiation; thus, whether clinical remission might be maintained long term and result in favorable renal outcomes remain to be determined.

\section{Conclusion}

In the patients with active IgA nephropathy, the clear benefit of concomitant use of the ARB candesartan with TSP in achieving clinical remission during early-phase of treatment, independent of its blood pressure-regulatory function, could not be demonstrated. TSP alone could suppress intrarenal RAS in the absence of RAS inhibition; moreover, about $50 \%$ of the patients achieved clinical remission, suggesting a primary role for inflammation in IgA nephropathy. In cases where clinical remission might not be achieved by TSP treatment, addition of an ARB such as candesartan, with titration as guided by residual urinary protein but not by blood pressure level, might be beneficial for achieving clinical remission. Further investigation is necessary to elucidate the role of TSP, RAS inhibition, and the combination of these distinct approaches in clinical remission of IgA nephropathy.

\section{Acknowledgements}

The authors thank the following colleagues for their invaluable advice and support: M. Nakachi, A. Hirano, J. Ishikawa, Y. Maehara, K. Tokashiki, Chinen S, M. Yamazato, and A. Ishida. We are also grateful to S. Hatoma and M. Ohta for their technical assistance. The authors would like to thank Enago (www.enago.jp) for their English proofreading services.

\section{Disclosure Statement}

This study was funded by Takeda Pharmaceutical Company Limited. The sponsor had no control over the study design, interpretation, writing, or publication of this work.

\section{References}

1 D’Amico G: The commonest glomerulonephritis in the world: IgA nephropathy. Q J Med 1987;64:709-727. 


\section{Kidney \\ Blood Pressure Research}

Kidney Blood Press Res 2018;43:780-792

\begin{tabular}{l|l}
\hline DOI: $10.1159 / 000489914$ & (C) 2018 The Author(s). Published by S. Karger AG, Basel
\end{tabular}

Published online: 22 May, 2018 www.karger.com/kbr

- Sugiyama H, Yokoyama H, Sato H, Saito T, Kohda Y, Nishi S, Tsuruya K, Kiyomoto H, Iida H, Sasaki T, Higuchi M, Hattori M, Oka K, Kagami S, Nagata M, Kawamura T, Honda M, Fukasawa Y, Fukatsu A, Morozumi K, et al.: Japan Renal Biopsy Registry: the first nationwide, web-based, and prospective registry system of renal biopsies in Japan. Clin Exp Nephrol 2011;15:493-503.

-3 Nair R, Walker PD: Is IgA nephropathy the commonest primary glomerulopathy among young adults in the USA? Kidney Int 2006;69:1455-1458.

4 Magistroni R, D’Agati VD, Appel GB, Kiryluk K New developments in the genetics, pathogenesis, and therapy of IgA nephropathy. Kidney Int 2015;88:974-989.

5 Locatelli F, Pozzi C, Andrulli S: IgA nephritis: ACE inhibitors, steroids, both or neither? Nephrol Dial Transplant 2006;21:3357-3361.

-6 Coppo R: Corticosteroids in IgA Nephropathy: Lessons from Recent Studies. J Am Soc Nephrol 2017;28:2533.

-7 Hotta O, Miyazaki M, Furuta T, Tomioka S, Chiba S, Horigome I, Abe K, Taguma Y: Tonsillectomy and steroid pulse therapy significantly impact on clinical remission in patients with IgA nephropathy. Am J Kidney Dis 2001;38:736-743.

-8 Reich HN, Troyanov S, Scholey JW, Cattran DC, Registry TG: Remission of proteinuria improves prognosis in IgA nephropathy. J Am Soc Nephrol. 2007;18:3177-3183.

-9 Tatematsu M, Yasuda Y, Morita Y, Sakamoto I, Kurata K, Naruse T, Yamamoto R, Tsuboi N, Sato W, Imai E, Matsuo S, Maruyama S: Complete remission within 2 years predicts a good prognosis after methylprednisolone pulse therapy in patients with IgA nephropathy. Clin Exp Nephrol 2012;16:883-891.

-10 Miyazaki M, Hotta O, Komatsuda A, Nakai S, Shoji T, Yasunaga C, Taguma Y and Japanese Multicenter Study Group on Treatment of IgA Nephropathy (JST-IgAN): A multicenter prospective cohort study of tonsillectomy and steroid therapy in Japanese patients with IgA nephropathy: a 5-year report. Contrib Nephrol 2007;157:94-98.

-11 Floege J, Feehally J: The mucosa-kidney axis in IgA nephropathy. Nat Rev Nephrol 2016;12:147-156.

$>12$ Suzuki Y, Suzuki H, Sato D, Kajiyama T, Okazaki K, Hashimoto A, Kihara M, Yamaji K, Satake K, Nakata J, Aizawa M, Novak J, Tomino Y: Reevaluation of the mucosa-bone marrow axis in IgA nephropathy with animal models. Adv Otorhinolaryngol 2011;72:64-67.

13 Liu LL, Wang LN, Jiang Y, Yao L, Dong LP, Li ZL, Li XL: Tonsillectomy for IgA nephropathy: a meta-analysis. Am J Kidney Dis 2015;65:80-87.

14 Wang Y, Chen J, Chen Y, Wang L, Lv Y: A meta-analysis of the clinical remission rate and long-term efficacy of tonsillectomy in patients with IgA nephropathy. Nephrol Dial Transplant 2011;26:1923-1931.

15 Kawamura T, Yoshimura M, Miyazaki Y, Okamoto H, Kimura K, Hirano K, Matsushima M, Utsunomiya Y, Ogura M, Yokoo T, Okonogi H, Ishii T, Hamaguchi A, Ueda H, Furusu A, Horikoshi S, Suzuki Y, Shibata T, Yasuda T, Shirai S, et al.: A multicenter randomized controlled trial of tonsillectomy combined with steroid pulse therapy in patients with immunoglobulin A nephropathy. Nephrol Dial Transplant 2014;29:15461553.

16 Matsuzaki K, Suzuki Y, Nakata J, Sakamoto N, Horikoshi S, Kawamura T, Matsuo S, Tomino Y: Nationwide survey on current treatments for IgA nephropathy in Japan. Clin Exp Nephrol 2013;17:827-833.

17 Miura N, Imai H, Kikuchi S, Hayashi S, Endoh M, Kawamura T, Tomino Y, Moriwaki K, Kiyomoto H, Kohagura K, Nakazawa E, Kusano E, Mochizuki T, Nomura S, Sasaki T, Kashihara N, Soma J, Tomo T, Nakabayashi I, Yoshida M, et al.: Tonsillectomy and steroid pulse (TSP) therapy for patients with IgA nephropathy: a nationwide survey of TSP therapy in Japan and an analysis of the predictive factors for resistance to TSP therapy. Clin Exp Nephrol 2009;13:460-466.

18 Fabiano RC, Pinheiro SV, Simões E Silva AC: Immunoglobulin A nephropathy: a pathophysiology view. Inflamm Res 2016;65:757-770.

19 Cattran DC, Greenwood C, Ritchie S: Long-term benefits of angiotensin-converting enzyme inhibitor therapy in patients with severe immunoglobulin a nephropathy: a comparison to patients receiving treatment with other antihypertensive agents and to patients receiving no therapy. Am J Kidney Dis 1994;23:247-254.

20 Praga M, Gutiérrez E, González E, Morales E, Hernández E: Treatment of IgA nephropathy with ACE inhibitors: a randomized and controlled trial. J Am Soc Nephrol 2003;14:1578-1583. 


\section{Kidney \\ Blood Pressure Research}

Kidney Blood Press Res 2018;43:780-792

\begin{tabular}{l|l}
\hline DOI: $10.1159 / 000489914$ & (C) 2018 The Author(s). Published by S. Karger AG, Basel
\end{tabular}

Published online: 22 May, 2018 www.karger.com/kbr

-21 Nishiyama A, Konishi Y, Ohashi N, Morikawa T, Urushihara M, Maeda I, Hamada M, Kishida M, Hitomi H, Shirahashi N, Kobori H, Imanishi M: Urinary angiotensinogen reflects the activity of intrarenal reninangiotensin system in patients with IgA nephropathy. Nephrol Dial Transplant 2011;26:170-177.

22 Kawamura K, Okada S, Li B, Suwa M, Yao J, Morioka T, Gejyo F, Oite T: Turbulence of glomerular hemodynamics involved in progressive glomerulosclerosis. Kidney Int 2006;69:1792-1798.

-23 Amorena C, Damasco C, Igarreta P, MacLaughlin M: Intrarenal renin-angiotensin system contributes to tubular acidification adaptation following uninephrectomy. Exp Nephrol 2001;9:60-64.

-24 Kobori $\mathrm{H}$ and Urushihara M: Augmented intrarenal and urinary angiotensinogen in hypertension and chronic kidney disease. Pflugers Arch 2013;465:3-12.

-25 Wolf G, Wenzel U, Burns KD, Harris RC, Stahl RA, Thaiss F: Angiotensin II activates nuclear transcription factor-kappaB through AT1 and AT2 receptors. Kidney Int 2002;61:1986-1995.

-26 Miyata K, Satou R, Shao W, Prieto MC, Urushihara M, Kobori H, Navar LG: ROCK/NF-кB axis-dependent augmentation of angiotensinogen by angiotensin II in primary-cultured preglomerular vascular smooth muscle cells. Am J Physiol Renal Physiol 2014;306:F608-618.

-27 Urushihara M, Ohashi N, Miyata K, Satou R, Acres OW, Kobori H: Addition of angiotensin II type 1 receptor blocker to CCR2 antagonist markedly attenuates crescentic glomerulonephritis. Hypertension 2011;57:586-593.

28 Matsuo S, Imai E, Horio M, Yasuda Y, Tomita K, Nitta K, Yamagata K, Tomino Y, Yokoyama H, Hishida A and Collaborators developing the Japanese equation for estimated GFR: Revised equations for estimated GFR from serum creatinine in Japan. Am J Kidney Dis 2009;53:982-992.

29 Szeto CC, Lai FM, To KF, Wong TY, Chow KM, Choi PC, Lui SF, Li PK: The natural history of immunoglobulin a nephropathy among patients with hematuria and minimal proteinuria. Am J Med 2001;110:434-437.

-30 Suzuki Y, Matsuzaki K, Suzuki H, Sakamoto N, Joh K, Kawamura T, Tomino Y, Matsuo S: Proposal of remission criteria for IgA nephropathy. Clin Exp Nephrol 2014;18:481-486.

-31 Soler MJ, Wysocki J, Batlle D: ACE2 alterations in kidney disease. Nephrol Dial Transplant.2013;28:2687-2697.

32 Katsurada A, Hagiwara Y, Miyashita K, Satou R, Miyata K, Ohashi N, Navar LG, Kobori H: Novel sandwich ELISA for human angiotensinogen. Am J Physiol Renal Physiol 2007;293:F956-960.

-33 Roberts IS, Cook HT, Troyanov S, Alpers CE, Amore A, Barratt J, Berthoux F, Bonsib S, Bruijn JA, Cattran DC, Coppo R, D’Agati V, D’Amico G, Emancipator S, Emma F, Feehally J, Ferrario F, Fervenza FC, Florquin S, Fogo A, et al.: The Oxford classification of IgA nephropathy: pathology definitions, correlations, and reproducibility. Kidney Int 2009;76:546-556.

34 Chan LY, Leung JC, Tang SC, Choy CB, Lai KN: Tubular expression of angiotensin II receptors and their regulation in IgA nephropathy. J Am Soc Nephrol 2005;16:2306-2317.

-35 Del Prete D, Gambaro G, Lupo A, Anglani F, Brezzi B, Magistroni R, Graziotto R, Furci L, Modena F, Bernich P, Albertazzi A, D’Angelo A, Maschio G. Precocious activation of genes of the renin-angiotensin system and the fibrogenic cascade in IgA glomerulonephritis. Kidney Int 2003;64:149-159.

-36 Shimizu A, Takei T, Uchida K, Tsuchiya K, Nitta K: Low-dose losartan therapy reduces proteinuria in normotensive patients with immunoglobulin A nephropathy. Hypertens Res 2008;31:1711-1717.

-37 Komatsu H, Fujimoto S, Hara S, Sato Y, Yamada K, Kitamura K: Effect of tonsillectomy plus steroid pulse therapy on clinical remission of IgA nephropathy: a controlled study. Clin J Am Soc Nephrol 2008;3:13011307.

-38 Navar LG. Intrarenal renin-angiotensin system in regulation of glomerular function. Curr Opin Nephrol Hypertens 2014;23:38-45.

39 Zamami R, Kohagura K, Miyagi T, Kinjyo T, Shiota K, Ohya Y. Modification of the impact of hypertension on proteinuria by renal arteriolar hyalinosis in nonnephrotic chronic kidney disease. J Hypertens 2016;34:2274-2279.

40 Kohagura K, Kochi M, Miyagi T, Zamami R, Nagahama K, Yonemoto K, Ohya Y: Augmented Association Between Blood Pressure and Proteinuria in Hyperuricemic Patients with Non-Nephrotic Chronic Kidney Disease. Am J Hypertens 2018;31:480-485.

41 Caliskan Y, Ozluk Y, Celik D, Oztop N, Aksoy A, Ucar AS, Yazici H, Kilicaslan I, Sever MS: The Clinical Significance of Uric Acid and Complement Activation in the Progression of IgA Nephropathy. Kidney Blood Press Res 2016;41:148-157. 


\section{Kidney Blood Pressure Research}

-42 Nakata J, Suzuki Y, Suzuki H, Sato D, Kano T, Yanagawa H, Matsuzaki K, Horikoshi S, Novak J, Tomino Y: Changes in nephritogenic serum galactose-deficient IgA1 in IgA nephropathy following tonsillectomy and steroid therapy. PLoS One 2014;9:e89707.

43 Leung JC, Tang SC, Chan LY, Chan WL, Lai KN: Synthesis of TNF-alpha by mesangial cells cultured with polymeric anionic IgA--role of MAPK and NF-kappaB. Nephrol Dial Transplant 2008;23:72-81.

44 Takase O, Marumo T, Imai N, Hirahashi J, Takayanagi A, Hishikawa K, Hayashi M, Shimizu N, Fujita T, Saruta T: F-kappaB-dependent increase in intrarenal angiotensin II induced by proteinuria. Kidney Int 2005;68:464-473. 